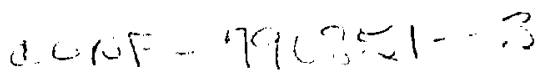

\title{
MODIFICATIONS IN OPTOELECTRONIC BEHAVIOR OF PLASMA-DEPOSTTED AMORPHOUS SEMICONDUCTOR ALLOYS VIA IMPURITY INCORPORATION
}

R. W. Griffith, F. J. Kampas, P. E. Vanier, and

M. D. Hirsch

Department of Energy and Environment

Broclihaven National Laboratory

Upton, NY, 11973, USA

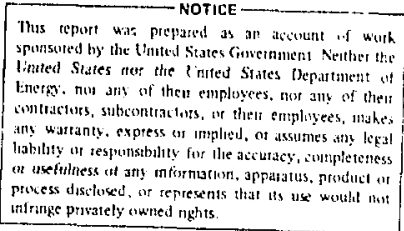

MASTER

By acceptance of this article, the publisher and/or recipient acknowledges the U.S. Government's right to retain a nonexclusive, royalty-free license in and to any copyright covering this paper. 
WODIFICAIIONS IN OPTOELZCTRONIC BERAVIOR OF PIASKA-DEPOSIIED AKHORPHOUS SEMICONDUCTOR ALLOTS TIA INPURITI DVCORPORATION*

8. H. Griffich, Z. J. Kampas, 2. E. Vanier, and Y. D. H1rsch

Department of Eaergy and Environment Brookhaven Nacional Laboratory Jptoo, ST, 11973, U.S.A.

\begin{abstract}
We discuse lectzonic properties of plasmi-deposited 2-51:H alloys as funcelons of oxygen and nterogen impuritias. Dver a rida range of processing condictons, Fencures displayed by the daca include: 1) "anomilous" bahavior in phococonductivity versus cemperature for films defictad in aleher, or both, inpuritiea (peaks appear that are assoclaced ulth thermal-quanching processes and supralinearity); and ii) modiffeat1on to "clasete" behavior in photoconductivity owing to synergistic effoces of oxygen end nitrogan. Corraletions with phocoluminescance are presenced. Opeical amissior spoceroscopy is discuseed within the context of an energing soectroscopy for the detection of antiring reactive species in the plesme. The presence of tepuriteles, parefcularly $\mathrm{s}_{2}$, ean be diagnosed.
\end{abstract}

\title{
INTRODUCEION
}

The distribution of gap states for rominally intefosic a-S1:a alloys ray seasitively depend upon the dagree of tecorporation of common ataospherte tapurtsies encourered in plasma deposition. For any glow-discharge deposition system, levels of alerogen and oxygen impurities are corzelated vith: 1 ) the qualieg of the vacuun (iniluenced by alr leaks, ousgassing of residual chember alr and motseure, backstreaming from puming syscems, erc.); and i1) the purity of process and carrter gases. The separate arfects of sach impurtty have already ben studied in the case of seactively sputcered a-51: $\mathrm{R}[1,2]$. In this paper, we give a prelintaary accour of corrala-

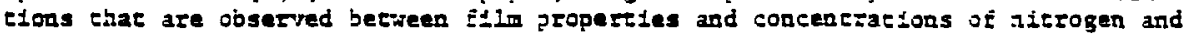
oxygta Impurites trezoduced foto the stlane gas stream. A fundamencal quescion arose during the course of this study: To what exact extent can the denstty-otscates distifbution (and the electronic propercies of films) be rantpulaced by the ecnerol of 1mpuricy levels in "a-51:a" pacertals?

\section{ETRERIMISTALL PROCEDURE}

Predominanty monohydrdde a-51:4 alloys were grown in a capact5strely-coupled g: glow-discharge zeactor with a noval high-vacuum capability. The base racuum was wi $\times 10^{-7}$ corr ac Is $\cong 270^{\circ} \mathrm{C}$. Yost fuIns were grown on the eachode with regacive blases 2-50 $\nabla$. Alloys reported upon here were produced under condittons $p=0.03$ 0.25 corr and $p=15-50 \mathrm{H}$. "Low 1mpurtiy" E1lm standerds were grown srom spectaliy disctlled s1lane concaining <s ppm $V_{2}$. Calibraced amounes of $N_{2}$ and $0_{2}$ (a.3., dilused is Ar) were added to the silane gas strand. Using IR transmission daca, tihe range of jydrogen concent in our films was calculated by two diffezent gethods in the Iiterature: $4-77[3]$ and $33-437[4]$, respectively.

Conduct Ivity neasurements vere made after samples vere annealed to $200^{\circ} \mathrm{C}$ in vacuum, and then glowly cooled. Photocurrent was reasured by chopping monochromeed lifint

*Work performed under the auspices of the U.S. Department of Energy. 
at $5 \mathrm{gz}$ and detecting the signal by lock-in techniques. In photoluninescence measuremenes, temperacure concrol over 4.2-300 $\mathrm{K}$ wes achieved by use of a concinuoustransfer cryogenic system. Zlasm species were nonicored by opefeal aniselon spectroscapy over the range $t=200-800$ ni using a 0.2 If $J-7$ nonochronator and Iamnatsu 2136 photomie1plier. Further decalls of procedure and results ulli be published elsewhere $[5]$.

\section{RSTLIS ANO OISCESSION}

A. Temperatura-Dependene Dark Conductiviey (DCT) and Photoconductivity (PCT).

51g. I 11lustrates ermsformat tous

1n DCF with impurity content of the

sllane gas stream. Low Impurity

Film a (cs ppa $\mathrm{N}_{2}$ ) exhlbits free

electron cranspore with ingle

act:vac 100 energz $E^{g}=\left(E_{C}-\bar{L}^{T}\right) x$

$1.1 \mathrm{eV}$. It is observad ior all

low 1mpurtty Ellas that ET lies be-

Low midgap. Without kowiedge of

any orher iflm impuritien, we can

only suppose the 3 ap seaces incrinsle to the a-51:H alloy per se pin $\mathrm{E}_{\text {F. }}$ PCI for a in $51 \mathrm{~g} .2$ is anomalous in appearance with low wagaltude and mictple peniks. The rature of such peaks till be discussed lacer.

Elin 'o $\left(600 \mathrm{ppm} \mathrm{I}_{2}\right)$ exhtbits hopplag =ranspore if DCT below $T=350 \mathrm{~K}$. in Ehe absence of added $\mathrm{O}_{2}$, ise observe Eor all processing condletons that $+150 \mathrm{ppa} \mathrm{R}_{2}$ is a chreshold for defect eransport in DCt. However at $50 \mathrm{H}$ and $250 \mathrm{H}$, excessive amounts of added $\mathrm{s}_{2}$ (e.3., $10^{4} \mathrm{ppm}$ ) changed the piasma chamistry sufficiencly that deFeces varn not inezoduced. The "anomalous" ?C2 for 'o is very gronounced, peaking at $2170 \mathrm{k}$.

As iypified by $512 \mathrm{~m} \mathrm{C}$ ( $1200 \mathrm{ppm} \mathrm{N}_{2}$, $700 \mathrm{ppe} \mathrm{O}_{2}$ ) to $51 \mathrm{~g} .1$, the add $1=10 \mathrm{~m}$ of oxpgen zerroves the nitrogenrelated derieces in DCT. Inder these condietons, onl7 12100 ppm $O_{2}$ removes hoppisg in DCF, but does hot stzongly modify the peak of 6 in 51g. 2. This resule toplies that recombinacton cencers rasponsible for cherael quenching in $2 C T$ are not the same scaces shec give stse to hopping if the dark. ?CI for c imporsanely exhibits rodification toward "classic" phococonducetvity [6] with increasing $\mathrm{O}_{2}$. (The resefgial valley

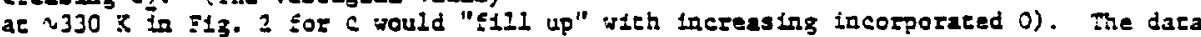
therefore todicate that $N$ and $O$ play a synergistic soie is erfecting the transformat1on Erom low impur1ey, anomalous FCI inco "class1e" ?CT.

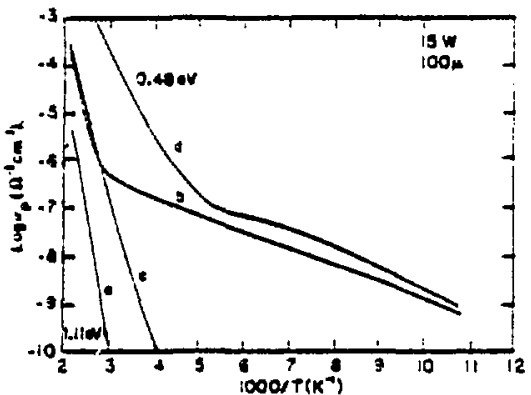

F1g. 1. DCT as $15 \mathrm{~N}, 100 \mathrm{i}$ EOr D1EEerent Impuricy Levels.

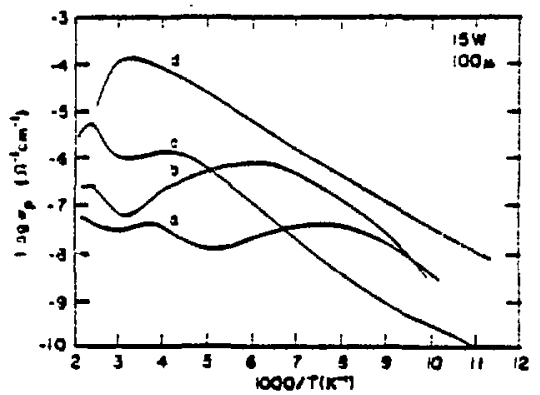

F士g. 2. Corresponding PCT. Flux $E_{\lambda}=$ $=1014 \gamma^{\prime} \cos ^{-2} s^{-1}$ ac $i=550 \mathrm{nos}$. 
Finally, Fila $d$ was produced in the presence of an als leak that raised the base vacurum to $2.4 \times 10^{-6}$ sorr. Consistane with $Z C$ and photoluminescence axcication spectra that show to change in optical zap, 1 in Fig. I shows evideace of electronic doping by $\$$ eine shifted $\mathrm{E}_{F}$ from below nidgap soward $\mathrm{E}_{\mathrm{C}}$ : $\mathrm{\Xi}_{0}=0.48 \mathrm{eV}$. PCT for $d$ exhibies classic (doped) behavior with nut $z 10^{-4} e^{2 y^{-1}}$ at $\xi_{\lambda} \cdot 10^{14} \mathrm{y}^{\prime} \mathrm{s}^{-2} \mathrm{~s}^{-1}$. The "anti-activacioa" energy",

$0.54<$, implies recombina-

eion cencers locacad ac $\left(\Sigma_{\Gamma} \varepsilon_{\mathrm{z}}\right) \mathrm{z}$

1.02 a (plus a posalble erap depeh $\Delta E)$. Below $* 300 \mathrm{~K}$, the aceivation enerzy ( $>0.09$ ev) is aither $\Delta E / 2$, with the recombineEton path directig between free electrons and staces " $r$ ", or it describes hopping amongst states below $\mathrm{s}_{\mathrm{C}}$.

51g. 3 111ustrates the preceding Esends at condttions $50 \mathrm{~N}, 250 \mathrm{u}$ : a (low impuriey); 6 ( 1000 ppm $\left.\mathrm{N}_{2}\right)$; $c\left(1000 \mathrm{ppm} \mathrm{O}_{2}\right)$; and $d\left(540 \mathrm{ppm} \mathrm{s}_{2}\right.$, 1000 ppur $\mathrm{O}_{2}$ ). Note $C$ shours etate 1000 ppu $\mathrm{O}_{2}$ dampeng peaks, but does not liminate theml. igatn, the $3 y \mathrm{ym}$ ergisetc effects of $O$ and $N$ are demonseraced: PCT for $a$ is mod1fied to the claseite behavior $d$.

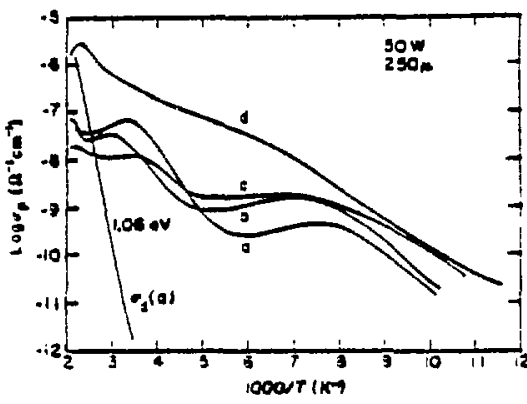

F1马. 3. $3 C \mathrm{C}$ and $D C T$ at $50 \mathrm{~W}, 250 \%$. $E_{\lambda}=1014$ i's $\mathrm{cm}^{-2} \mathrm{~s}^{-1}$ at $i=550 \mathrm{~nm}$.

F15. 4 1IIuscrates PCI and DCT for a f1Im (600 ppm $\left.N_{2}, 100 \mathrm{ppm} \mathrm{O}_{2}\right)$ at low power and very low pressure. As lierle as $100 \mathrm{ppm} \mathrm{O}$ removed hopping in DC.. The anowalous peak became less prominear ar̃er in annesl at $350^{\circ} \mathrm{C}$ for W $13 \mathrm{~h}$. This ung todicate partial recoval of cencers that induce Eberal quanching.

Intenstey dependances of a peak in PCI are shown to 518 . 5. (Gas impurtey is $600 \mathrm{ppm} \mathrm{N}_{2}$ ). With ircreasing lorensity $\overrightarrow{\hat{f}}$, the peak shifes to higher $\vec{t}$. $\sigma_{p} n \mathrm{~g}^{2}$ is slighely supralinear $(v=1.2)$ in a ragion of the thermal quenching (high-I side of peak), and tends coward jtmolecularicy ( $(\nu=0.5)$ on the low-I side. "Anounlous" peaks in PCT persist 2 inder the following conditions: 1) broadband 1IIumination $(450-650 \mathrm{am})$; 11) dc mesurement (no chopping); and 1ii) elther heating or cooing (Imlytog no thermally-stimiared curreats).

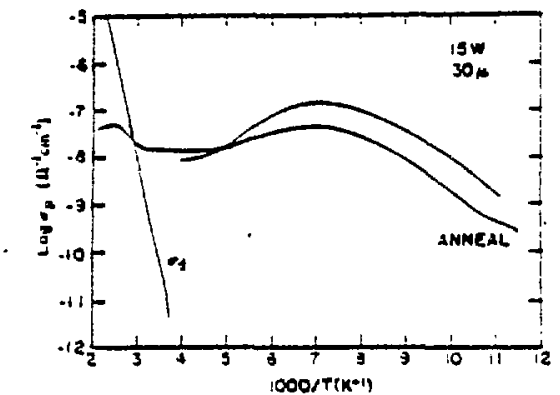

F13. 4. Anomalous PCT at is $\pi, 30 \%$ Befora and After Long-iern ineal.

The phenomena of chermal quenching and supralinearicy ware previously observed in a variety of materials: CdSe: $\left[: C_{1}[7]\right.$, Ga:in [3], and possibit in a-zase [9]. The essence of such anomalous behavior ${ }^{3}$ is contained in the following simpla nodel [10]. Suppose there extst swo Ievels of recombination centers located at $\Xi_{2}>\Xi_{5}>\Xi_{1}$ with

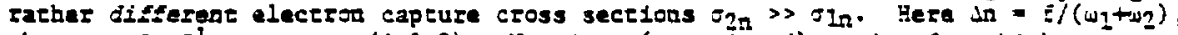
where $\omega_{1} \equiv \tau_{I}^{-1} \equiv \sigma_{1 n} p_{T-1}(1=1,2)$. Now in a (resericted) region Eor which $\omega_{2}>w_{1}$,

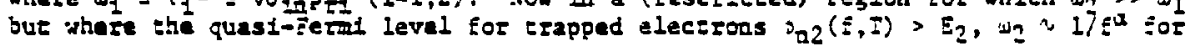


Incraseing $E$, and so supralinaarity sesules: in 2 f/ur $\sim$ elta. Thereal queaching occurs for facreasing I slace $p_{\mathrm{a} 2}-E_{2}$ loplies laczensing $\omega_{2}$ relacive so it?. Thus in $-E / \omega_{2}$ <c $\leq / \omega_{1}$. Aceivaejoa on the low-T side of the peatk occurs because the recombinetion pach to donthanc staces "l" proceede through electron iraps (gentrace-palr processes tad also be lnvolved). Joldently, the szrergism of $O$ and $N$ supprases eacers (states " 2 ") thet cause thermal quenching, as 1liustrated by eransformetions $a-c$ and $a+d$ in Figs. I and 3 , zespectively. If phoroeranspore is bipolar ac low $I$, then an axnceIy symancical argument holds for holes",

3. Specrzal and TemperatureDependent Fhotoluminescence (PLI)

T2 andssion sp: int ac $50 \mathrm{~K}$ are 11luserated in $5 \$ 8$. 6 sor some Eilms of Elgs. $L$ and 2. Except For the doped film $d$, 311 spectre are dowineted by the canoolesl peak at 21.3 ov $[11,12]$. This peax also dominates in :11ms with: 1) $N$ impurter alone ( $\leq 10^{4}$ opm $\left.N_{2}\right)$; 11) o alone ( $\leq 1000$ ppm $\left.\mathrm{O}_{2}\right)$; and $1 \pm 1$ ) boeh inpurittes, in ehe absence of pronounced shifts of $E_{g}$ (as for $c$ ). Oxygenaced ElIms show no hine of the serougly ehereallyquenched pexk near 1.1 eV associaces with charged defects of nonbridgtag oxygen (13). Concelvably, higher Ievels of $O_{2}$ in the gas strean could exeece such defect, after sacurating all bridging jites $51-0-5 i 1$.

By contrast, the $2 L$ spectrim Eor F1lon d exhibits a peak near 1.0 eV that strongly dominates the sanonieal couporent at all $I Z 4.2 \mathrm{~K}$ (see 713.7 ). Since this lowenerg componene is not rapldly quenched with $\vec{i}$ it cannos be confused vits il inrr. Iving an oxygen-related charged defect. Instead, it probably involves an in$t 2$ 'natc defect in a-s1:E that is inczoduced by nitzoger doping. Indeed, a loweaceg component in ?I $(0.8-0.9 \mathrm{~V})$ that persists to high $t$ was E1rst noted in she case of phosphorus doptag [14], and any even be related to def́ects in c-s1 introduced by 100 implancacton $\{15\}$.

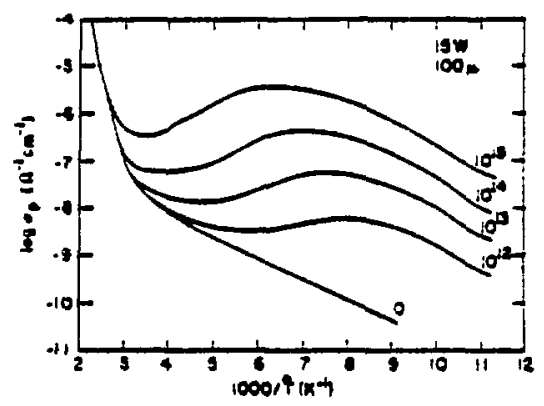

I1g. 5. Intensity Dependences or

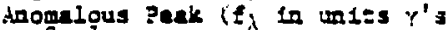
$\mathrm{con}^{-2} 3^{-1} ; .2550$ 2m).

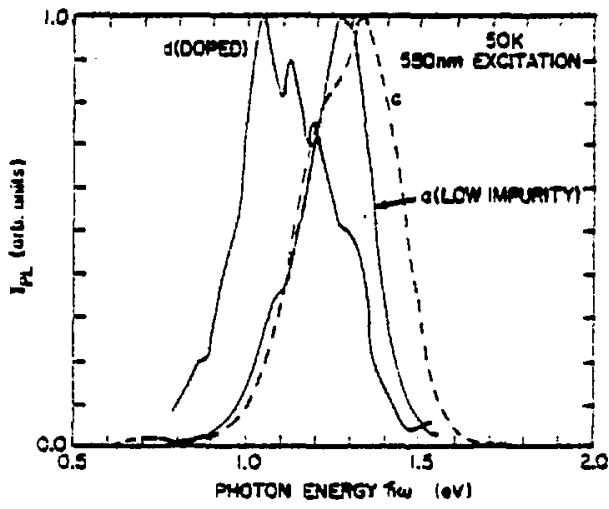

F13. 6. Spectral DL For Different Impurtey Lavels (Eringes due =0 Interference affects). 
F18. 7. PLI for Entse100 Compcones of Doped Filn d. Comparison with Canosteal Corponent of Low Inpurity Film a. (Arb. Vormal1zat 100).

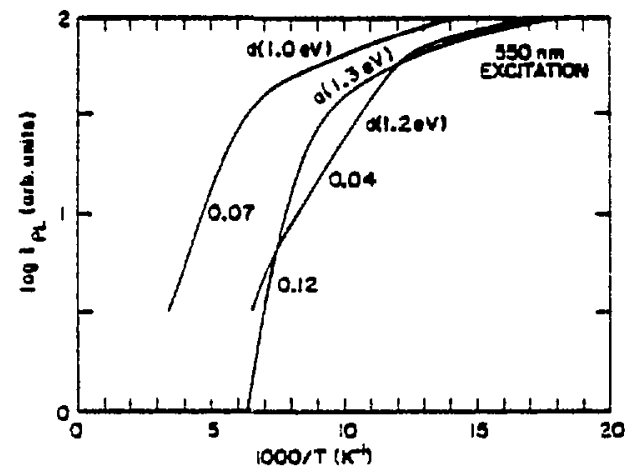

C. Opteserl Emissioa Speceroscopy (OFS)

OES is a non-perturbative cechalque used to detece emleting finctive species in the planms. Complemented by other technlques, OES ouy lead 50 an understandtog st :he relactoaships amoog the plasw shemlatry, bhe surface reactions that prowote film 350wth, and the elecezenic (and alcroseructural) properties of silms.

The threshold for decomposictor of $51 \mathrm{H}_{4}$ is $7.5 \mathrm{QV}$ (10 photolysts), productag pri-

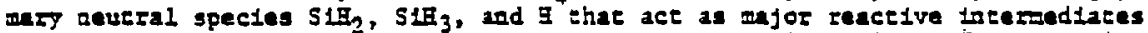

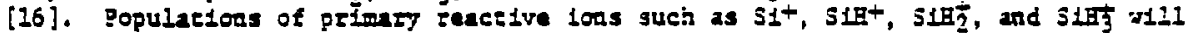
in general be ang orders of ragnitude below the reucrals, since electron energies $>11.7$ ov are required for 10n1zation. E1s. 8 la part of a representative speceran eaken duriag tifin deposic 100 w1eh $500 \mathrm{ppm}$ added $\mathrm{N}_{2}$. The Eollown ing sefor species rere 1dentified: 51 (288 nIm, $391 \mathrm{gm}) ; 51 \mathrm{It}(14 \mathrm{~nm})$; $\mathrm{H}_{2}(450-630 \mathrm{am}) ; 3 \mathrm{almer}$ series $\mathrm{kg}(486 \mathrm{am})$ and $I_{n}(556 \mathrm{am}) ; V_{2}$ $\left(\bar{C}^{3} \pi+3^{3} \pi\right) ;$ and more centacively $S \pm H^{+}(399 \mathrm{~cm})$ and SICI (28I am). $y_{2}$ is, so doube, a ubiquiteous smourtey of the usual plasma depoatition sysEem. The detection

level here was $\sim 50 \mathrm{ppm}$

$\mathrm{N}_{2}$. SICI was only

present in silane that ins specinlly destlled to eliminate $v_{2}$ (<5 ppm). Sow iflm properity dependences upon silane tanks way be aterfbucable to this erzee in-

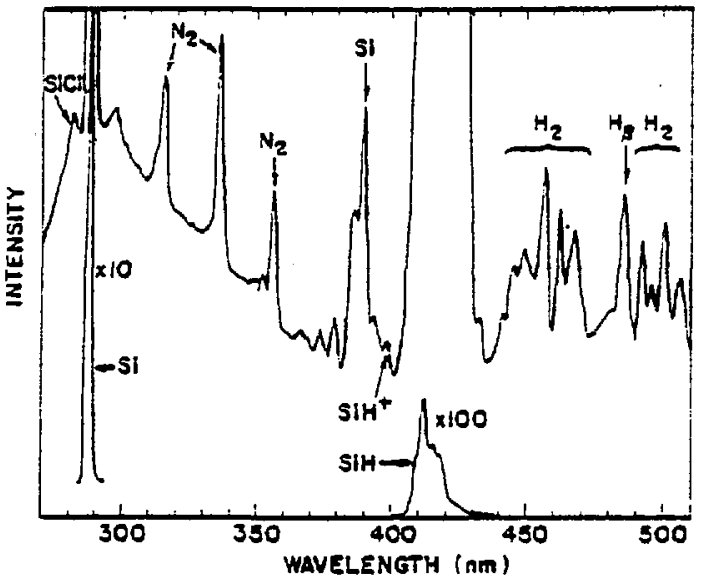

E1g. 8. OES of ?lasm with 500 ppon Added $\mathrm{x}_{2} . \quad(50 \mathrm{H}, 250 \mathrm{H})$.

purte7; 15s detection demonserates the sersicivity of OES. A Jeakess of OES is that potentially important species, such as $S I_{2}$, absorb but do not emit between 
200-800 ax.

Fta. 9 depicrs increseing amission incensity with power, and hence with election temparatuze and changtng energy diseribueton. This Figure IIjistiates the sensitive dependence of tha plasma chardstry upon the processing condstione, the subject or a conefnutig seudy.

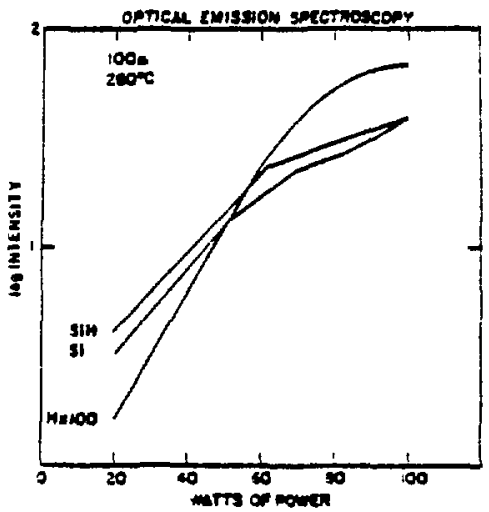

51g. 9. OES Intenstef versus Zower Lor $5.47(414 \mathrm{2m}), 5:(288 \mathrm{2m})$, and $\vec{n}_{3}(656 \mathrm{am})$.

\section{ACENOWLEDGMarTs}

ii. wist to thank h. E. Dolahoy Sor useful discusslons, and R. Gremme for technical assistance.

\section{soOTHOTES}

1. $1000 \mathrm{ppm} O_{2}$ In the gas seream corresponds to 1 it bonded 0 in the bridging sorIfguracion $\$ 1-0-51$ as eselmated izom the anctsyumetzls serecsh wode at $i=980 \mathrm{~cm}^{-1}$.

2. We thank Y. Jrodsky and I. Tledje for proposing some of these ceses.

3. Detalled compueregeceraced fics to daca w11 be jublished alsewhere.

4. In the case of alectron piocorzanspore, staces "I" say perinaps be relaced so Spari's E, states.

\section{REFERENCES}

(1) Paesler, Y. A. ec al, Phys. Scv. Lace. 41 (1978) 1492.

[2] Balxeras, J., Sencaraglia, D., tnóro, P., ?hil. Mag. 337 (1978) 403.

[3] Zanzucchi, P. J., Wronski, C. 3., and Cazlson, D. E., J. Appl. 2h7s. 48 (1977) 5227.

[4] Brodsky, Y. H., Cardona, Y., Cuomo, J. J., Phys. Rev. 316 (1977) 355ó.

[5] Brookhaven Grous, to be pubitsined.

[6] Amoldussen, [. C. ef al, J. Appl. Phgs. 43 (1972) 1798.

[7. 3ube, R. H., J. Phys. Chem. Solids 1 (1957) 234.

[8] Nerman, R. at al, Phys. Rev. 102 (1956) 613.

[9] 3rodie, D. E., In: Spear, $\%$. 三. (ed.), Amor, and LIq. Semicond., p. 472 (U. of Edinburgh, Edirburzi, 1977 ).

(10) See, Eor example, Rose, A., Fhys. Rev. 97 (1955) 322.

[11] Sagemenn, D. and Flscher, K., In: Lucovsky, G. and Galeener, E. L. (eds.), Struceure and ExétzrLons, p. 37 (A.I.Z., New York, 1976).

[12] Sereec, R. A., Ph11. Yag. 337 (1978) 35.

[13] Street, R. A., Knighes, J. C., and Bfegelsen, D. K., Fhys. Rev. 318 (1978) 1880 .

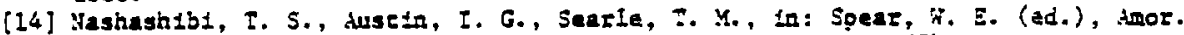
and LIq. Semicond., p. 392 (Q. of Edinburgi, Edinourgi, :977).

[15] Pankove, J. I., and wu, C. ?., Bul1. Amer. Phys. Soc. 24 (1979) 435.

[16] Perkins, G. G. A., tustin, E. R., Lampe, 5. N., J. Amer. Chem. Soc. 101 (1979) i109. 